\title{
MANAJEMEN PENDIDIKAN AGAMA ISLAM DALAM KELUARGA
}

\author{
Mira Shodiqoh \\ IAINU Tuban \\ Email: mirashodiqoh@stitmatuban.ac.id \\ Fashi Hatul Lisaniyah \\ IAINU Tuban \\ Email: fashihatullisaniyah@stitmatuban.ac.id
}

\begin{abstract}
Abstrak
Keluarga adalah tempat pertama dalam membentuk kepribadian manusia dan tempat di mana ia mendapatkan kasih sayang, menumbuhkan perasaan, dan mengetahui citacita. Orang tua adalah anggota keluarga paling awal dan pertama yang terlibat dalam pembentukan kepribadian. Orang tua (bapak dan ibu) memegang peranan penting dan sangat berpengaruh terhadap pendidikan anak-anaknya, karena sejak lahir kedua orang tua adalah orang yang mendampingi mereka. Ibu adalah sosok pertama yang dikenal dan ditiru oleh temperamen anaknya. Oleh karena itu dalam ajaran Islam tanggung jawab mendidik anak sebenarnya dimulai ketika seseorang memilih pasangan hidup (istri). Artikel ini bertujuan untuk mengetahui: 1. Bagaimana pengelolaan pendidikan agama dalam keluarga, 2. Bagaimana pengelolaan pendidikan agama pada anak, 3. Bagaimana pengelolaan pendidikan agama pada remaja, dan 4. Bagaimana pengelolaannya. pendidikan agama pada orang tua. Pengelolaan pendidikan agama pada anak merupakan langkah awal yang baik untuk menanamkan nilai-nilai agama agar anak yang tumbuh dengan prinsip akhlak yang baik, aqidah, beribadah dan mendidik anak sejak dini akan menghasilkan output yang maksimal. Pengelolaan pendidikan remaja membutuhkan pengawasan dari orang tua yang begitu serius dengan menanamkan kegiatan seperti klub remaja, majelis Islam, kegiatan aktif di masjid, atau kegiatan bernuansa islami terhadap remaja sebagai salah satu bentuk pembentukan karakter. Hal ini untuk menghindari perilaku negatif terhadap remaja. Manajemen pendidikan pada orang tua didasarkan pada berbagai pendekatan. Ini dapat dilakukan untuk siapa saja seperti pendekatan yang rasional, persuasif, masuk akal, dan spiritual
\end{abstract}

Kata Kunci: Manajemen, Pendidikan, Agama Islam, Keluarga.

\section{PENDAHULUAN}

Pendidikan tidak dapat dipisahkan dari tiga hal, yaitu keluarga, sekolah, dan masyarakat. Keberhasilan pendidikan dalam suatu Negara atau daerah tergantung kepada tiga faktor tersebut. Ketiganya mesti bersinergi dalam mengelola dan mengembangkan pendidikan. Dan setiap faktor tersebut mempunyai fungsi dan peranan yang sangat penting untuk mencapai tujuan pendidikan. Tetapi dalam makalah ini tidak akan dibahas ketiga faktor itu, namun yang akan dibahas hanya terfokus pada salah satu faktor dari ketiga faktor tersebut, yaitu keluarga.

Mujamil Qomar (2013: 1) Pendidikan dalam keluarga merupakan pendidikan yang pertama dan utama. Sebagai pendidikan yang pertama, pendidikan dalam keluarga menempati urutan paling 
awal dalam perjalanan proses pendidikan yang dialami seseorang. Pendidikan dalam keluarga mendahului semua jenis pendidikan yang diterima dan dialami semua orang. Pendidikan dalam keluarga mampu mendasari dan mewarnai corak kepribadian seseorang dalam seluruh perjalanan hidupnya. Pengalaman-pengalaman yang diserap masa kecilnya sangat berpengaruh pada perilaku individual dan perilaku sosialnya dalam pergaulan hidup ditengah masyarakat. Apalagi masa kecil merupakan masa emas bagi penanaman, pembentukan, dan pengembangan intelektual, perilaku, kebiasaan, dan karakter seseorang.

Pendidikan agama Islam untuk setiap manusia sangat diperlukan dari kalangan anak-anak sampai kalangan orang tua. Sebagai suatu bentuk pengetahuan tentang agama maka bukan hanya kalangan anak-anak yang memperoleh pendidikan agama akan tetapi kalangan remaja sampai orang tua perlu menanamkan pengetahuan agama. Hal tersebut sesuai dengan firman Allah, sebagai berikut:

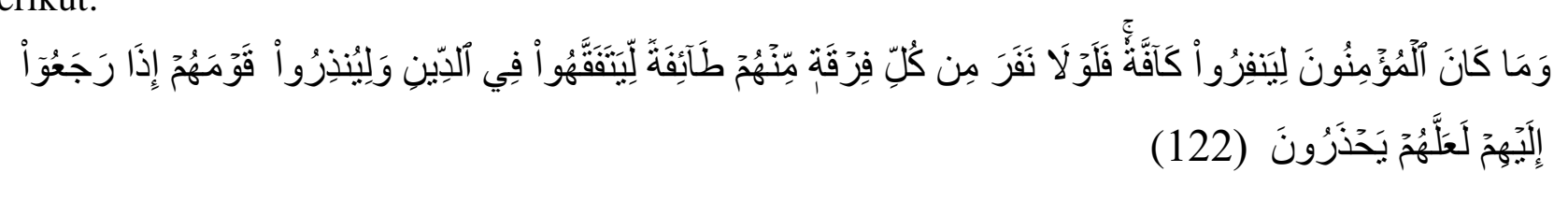

Artinya: "Tidak sepatutnya bagi mukminin itu pergi semuanya (ke medan perang). Mengapa tidak pergi dari tiap-tiap golongan di antara mereka beberapa orang untuk memperdalam pengetahuan mereka tentang agama dan untuk memberi peringatan kepada kaumnya apabila mereka telah kembali kepadanya, supaya mereka itu dapat menjaga dirinya” (QS. at-Taubah: 122).

Di dalam ayat tersebut dijelaskan bahwa Allah memerintahkan setiap orang untuk memperdalam pengetahuan tentang agama karena agama dapat menjaga diri yang artinya menjaga sikap ketauhidan, syariat, dan beberapa nilai-nilai keislaman.

Dewasa ini perkembangan anak pada dunia sosial media sangat cepat bahkan anak sekarang sudah jarang bermain sesama sebayanya mereka lebih berinteraksi individu seperti bermain game, bermain media seperti hp dan komputer. Hal ini karena pengaruh globalisasi semakin cepat sehinga dapak negatif maupun positif datang secara tiba-tiba. Perlu adanya pengawasan ketat orang tua terhadap anak agar anak tumbuh dengan nilai-nilai yang baik dan agamis. Oleh karena itu peran orang tua sangat besar untuk menjadikan anak lebih sholeh dan sholehah. Pendidikan agama pada anak sangat diperlukan dan harus ditanamkan setiap anak baru berkembang karena dari sini anak memang harus dibimbing dalam aktivitasnya, baik dari aktivitas belajar, bermain maupun sekolah. Yang perlu ditanamkan pada anak ialah pendidikan akhlak, anak diajarkan berbicara sopan, mengajari tata kerama, mengajak belajar agama, memberi wawasan luas agar anak dapat tertanam sejak dini tentang nilai-nilai norma agama maupun sosial. 
Maraknya remaja yang tergiur ke dunia anarki maupun kejahatan disebabkan karena remaja memang sejatinya mencari jati diri. Pengawasan anak remaja berbeda dengan pengawasan anak karena remaja berbeda dari karakteristinya sikap, perilaku maupun fisik mengalami perubahan yang signifikan dari masa anak-anak sampai remaja. Tidak heran jika remaja cepat tersinggung, cepat nakal, capat mempengaruh orang lain. Hal ini orang tua sulit mengawasi anak yang sedang berbunga mekar dalam masanya. Untuk itu orang tua harus mampu membatasi anaknya yang sedang bergulir masa remajanya dengan berbagai pendekatan agamis, aktivis sosialis, maupun kegiatan yang sifatnya positif. Ini dapat mempengaruh positif bagi anak remajanya. Karena itu orang tua selalu memberi motivator atau motivasi untuk anaknya agar bisa berfikir masa depan dengan baik.

Pendidikan agama pada orang tua sangat sulit jika dilakukan oleh keluarganya, karena mungkin orang tua merasa lebih luas pengetahuanya, orang tua lebih dihargai bahkan mungkin orang tua sudah merasa sulit untuk diarahkan. Banyak kita temui orang tua yang belum bisa membimbing anaknya dengan baik. Faktor ini disebabkan karena kurangnya pengalaman dari orang tua, kurangnya pendidikan agama dari orang tua (Cristiana, 2018; 218). Namun sebaliknya ada orang tua tidak mempunyai kompetensi mengajar kepada anaknya akan tetapi orang tua lebih mengikuti pengajian di lingkungan sebagai pendidikan agama. Ini yang akan tertanam dalam jiwa orang tua yang akan mencerminkan kesadaran bagi orang tua. Namun tidak semua orang tua mau seperti itu, lebih banyak orang tua dengan kesibukanya sehingga merasa belum ada waktu atau kesadaran.

\section{ISI DAN PEMBAHASAN}

\section{PENTINGNYA MANAJEMEN PENDIDIKAN AGAMA ISLAM DALAM KELUARGA}

Pendidikan dalam keluarga merupakan pendidikan yang pertama dan utama. Sebagai pendidikan yang pertama, pendidikan dalam keluarga menempati urutan paling awal dalam perjalanan proses pendidikan yang dialami seseorang. (Qomar, 2013: 1). Anak pada mulanya cenderung melakukan sesuatu berdasarkan apa yang dilihat, didengar, disaksikan, dirasakan dan dialaminya sebelum mendapat pengaruh dari luar baik pergaulan maupun pendidikan. Peran dan pengaruh pendidikan dalam keluarga sangat besar terhadap kepribadian anak bahkan sampai dewasa sekalipun. Kondisi dalam keluarga yang berperan dan berpengaruh terhadap kehidupan seseorang itu bisa berbentuk kondisi sosial, kondisi ekonomi maupun kondisi pendidikan Agama Hal ini sesusai dengan penelitian isnawati dan dina (2017) yang menyatakan keluarga mempunyai peran yang sangat penting dalam pembentukan kepribadian seseorang. 
Selanjutnya, peran dan pengaruh pendidikan Agama dalam keluarga memiliki kontribusi terhadap pendidikan yang berlangsung di sekolah. Tafsir (1992: 158) menegaskan bahwa kunci keberhasilan pendidikan Agama di sekolah bukan terletak pada penggunaan metode pendidikan dan penguasaan bahanya, melainkan pada pendidikan Agama dalam rumah tangga. Inti pendidikan agama dalam keluarga itu adalah hormat kepada Allah SWT, orang tua dan guru. Maka intensitas dan optimalisasi pendidikan Agama dalam keluarga sangat membantu guru Agama dalam mengembangakan kepribadian Muslim, terutama pada peserta didik. Guru agama kemudian melanjutkan upaya-upaya transformasi perilaku peserta didik berdasarkan nilai-nilai ajaran Islam yang telah diserap dalam kehidupan keluarga. Oleh karena itu pendidikan Agama dalam keluarga perlu di manage secara maksimal.

Dari beberapa penjelasan diatas dapat di tarik suatu kesimpulan Bahwasanya keluarga adalah tempat pertama untuk seorang anak memperoleh pendidikan, dan keluarga sangat berperan penting terhadap pembentukan karakter serta kepribadian seorang anak bahkan sampai seorang anak menginjak usia dewasa. Sebagai suatu analogi Seorang anak yang dibesarkan dari keluarga yang kurang begitu bagus, dan ketika anak pada saat itu terbiasa mendengar keluarganya berbicara kasar maka bisa dipastikan bahwa pengalaman yang mereka terima sehari-hari dalam keluarga merupakan pengalaman yang kasar. Demikian juga sebaliknya ketika mereka cenderung mengekspresikan ucapan maupun tindakan yang santun, adalah semata-mata sebagai refleksi dari pengalaman dan kebiasaan dalam keluarganya.

Oleh karena itu pendidikan yang akan diterapkan dalam keluarga harus benar-benar dimanajemen dengan baik. Karena pendidikan dalam keluarga itulah awal dari pembentukan karakter seorang anak.

Tentang kewajiban pendidikan dalam keluarga terdapat dalam Al-Qur'an Surah Al-Tahrim (66) ayat 6 , Allah berfirman:

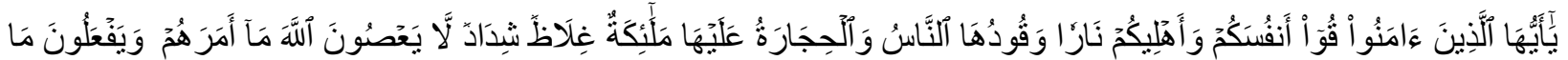

$$
\begin{aligned}
& 7
\end{aligned}
$$

Artinya: "Hai orang-orang yang beriman, peliharalah dirimu dan keluargamu dari api neraka yang bahan bakarnya adalah manusia dan batu; penjaganya malaikat-malaikat yang kasar, keras, dan tidak mendurhakai Allah terhadap apa yang diperintahkan-Nya kepada mereka dan selalu mengerjakan apa yang diperintahkan”.

Ayat ini menggambarkan seruan Allah kepada orang-orang mukmin agar mereka menjaga diri dan keluarganya dari siksaan neraka, dimana neraka itu dijaga oleh para malaikat yang amat kasar. Dan mereka tidak pernah melanggar ketentuan Allah. 
Pendidikan keluarga itu dimulai dari kedua orang tua, mereka mesti saling menghormati dan melaksanakan kewajiban mereka masing-masing. Selain itu mereka juga dituntut untuk selalu berbenah diri untuk menjadi insan yang shaleh dan bertaqwa kepada Allah. Kondisi ini merupakan tonggak utama dalam pendidikan keluarga. Kebiasaan orang tua dalam keharmonisan dan ketaatan kepada Allah dapat mempengaruhi anak-anak dalam keluarga tersebut.

Secara tegas ayat 6 surah al-Tahrim di atas mengingatkan semua orang-orang mukmin agar mendidik diri dan keluarganya kejalan yang benar agar terhindar dari neraka. Ayat tersebut mengandung perintah menjaga, yaitu “qu” (jagalah). Perintah menjaga diri dan keluarga dari neraka berkonotasi terhadap perintah mendidik atau membimbing. Sebab didikan dan bimbingan yang dapat membuat diri dan keluarga konsisten dalam kebenaran itu membuat orang terhindar dari api neraka. Oleh karena itu para orang tua berkewajiban mengajarkan kebaikan dan ajaran agama kepada anak-anak, menyuruh mereka berbuat kebajikan dan menjauhkan kemungkaran dengan membiasakan mereka dalam kebenaran atau kebaikan tersebut, serta memberikan contoh teladan.

Di antara usaha pendidikan yang dapat dilakukan orang tua adalah mengajak semua anggota keluarga bertobat kepada Allah. Orang tua berkewajiban membimbing dan mendidik anaknya, serta mengajak mereka selalu memohon ampunan dari Allah, menyesali perbuatan salah yang pernah dikerjakan, jika memang benar-benar bertobat kepada-Nya dan tidak akan kembali lagi kepada perbuatan tercela yang telah dilakukan tersebut. Dan sebagai balasan bagi orang-orang yang benarbenar bertobat, maka Allah menyediakan surga baginya.

Perintah mendidik keluarga juga tergambar dalam surat Taha (20) ayat 132, yaitu:

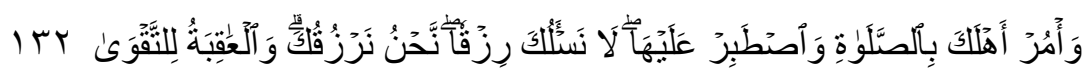

Artinya: “ Dan perintahkanlah kepada keluargamu mendirikan shalat dan bersabarlah kamu dalam mengerjakannya. Kami tidak meminta rezki kepadamu, kamilah yang memberi rezki kepadamu. dan akibat (yang baik) itu adalah bagi orang yang bertakwa”.

Lebih tegas ayat ini memerintahkan setiap orang tua, terutama ayah sebagai kepala keluarga, memerintahkan anggota keluarganya mendirikan shalat. Dalam suatu riwayat ditegaskan bahwa nabi bersabda yang maksudnya; "suruhlah anakmu mengerjakan shalat ketika berumur tujuh tahun, dan apabila anak itu sudah berusia sepuluh tahun tidak mau juga mengerjakan shalat maka berikanlah hukuman keatasnya". Riwayat ini menggambarkan, bahwa orang tua berkewajiban memerintahkan anak-anaknya menjalankan perintah agama terutama shalat.

Kewajiban memerintahkan anggota keluarga mengerjakan shalat berarti wajib pula bagi kepala keluarga mengajarkan anggota keluarganya hal-hal yang berkaitan dengan pelaksanaan 
shalat. Demikian pula mendidik anggota keluarga dalam mendirikan shalat orang tua dituntut kesabaran dan keuletan dalam mendidik anggota keluarga terutama anak-anaknya.

Dari beberapa uraian di atas dapat disimpulkan bahwasanya Pendidikan dalam keluarga bila dipandang dari perspektif agama sangat jelas tertera dalam al-Qur'an surah al-tahrim ayat 6 serta al-Qur'an surah Taha ayat 132 tersebut, menggambarkan kewajiban suatu keluarga mendidik dan membimbing anggota keluarganya. Dari sini dapat diartikan pula, bahwa kesepakatan antara seorang laki-laki dan wanita untuk menikah mestinya dimaknai sebagai kesepakatan mereka mendirikan lembaga pendidikan keluarga, dimana suami dan istri (ayah dan ibu) sebagai murabbi atau mu'addib (pendidik) dan anggota keluarga lainya khususnya anak sebagai peserta didik. Untuk itu, menjadi seorang ayah atau ibu mestilah memenuhi persyaratan seorang pendidik, khususnya penguasaan minimal ilmu keislaman dan keteladanan. Karena pada hakikatnya proses pendidikan keluarga dimulai semenjak pemilihan atau penentuan jodoh.

\section{MANAJEMEN PENDIDIKAN AGAMA ISLAM PADA ANAK}

Menurut Arnold Gessel Anak pada usia bayi sudah mempunyai perasaan ketuhanan (Syamsul yusuf, 2011;161). Perasaan ini sangat memegang peranan penting dalam diri pribadi anak. Perasaan ketuhanan pada masa usia ini merupakan fundamen bagi pengembangan perasaan ketuhanan periode berikutnya. Seiring dengan perkembangan kognisi, emosi dan bahasa anak. Maka, untuk membantu perkembangan kesadaran beragamanya orang tua sebagai lingkungan pertama bagi anak seyogyanya melakukan hal-hal sebagai berikut:

a) Kenalkan konsep-konsep atau nilai-nilai agama kepada anak melalui bahasa, seperti pada saat memberi makan, menyusui, memandikan, membedaki, memakaikan pakaian pada anak maka ucapkanlah basmallah, dan bacakanlah hamdalah, setelah selesai.

b) Memperlakukan anak dengan penuh kasih sayang. Hal ini penting karena pada usia ini belum berkembang pemahaman akan kasih sayang Tuhan. Melalui kasih sayang orang tua, anak akan menaruh sikap percaya kepada orang tua, dan bersikap positif terhadap apa yang disampaikan orang tuanya. Sikap-sikap ini akan membawa pengaruh yang sangat besar terhadap kesadaran beragama anak. Pada diri anak akan berkembang bahwa agama adalah sesuatu yang menyenangkan.

c) Memberi contoh dalam mengamalkan ajaran agama secara baik. (Qomar, 2013: 8) Karena anak memiliki kemampuan mengimitasi penampilan atau perbuatan orang lain/ orang tuanya. Karenanya oarng tua harus tampil sebagai figur yang memberi teladan dalam 
mengamalkan nilai-nilai agama pada anaknya. Keteladanan itu seperti, mengamalkan shalat, berdo'a, tutur kata yang sopan, menjaga kebersihan dan sebagainya.

Dari uraian diatas dapat ditarik kesimpulan Bahwasanya, setidaknya, dengan tiga upaya yang orang tua lakukan untuk menanamkan rasa keberagamaan anak, maka pengetahuan anak tentang agama terus berkembang.

Menurut Drajat (1989:58-59) dalam bukunya Ilmu Jiwa Agama membagi usia anak kepada pertama, 0-6 tahun, kedua, anak umur 6-12 tahun. Anak pada usia sekolah (6-12 tahun) masa ini ditandai dengan perkembangan intelegensi yang pesat, mereka ingin mengetahui segala sesuatu dan berfikir secara logis. Keinginanya untuk mengetahui dan mencintai kebenaran yang diterapkan pada segi kerohanian.

Memperhatikan pentingnya pendidikan pada anak, maka dapatlah diambil suatu langkahlangkah dalam menciptakan jiwa keagamaan pada anak yaitu selain melakukan diawali dengan memilih pasangan hidup sesuai dengan ajaran Islam dan juga melakukan apa-apa hal-hal yang dianjurkan ketika anak tersebut masih berada dalam kandungan baik sang ibu maupun sang bapak dan melakukan apa-apa yang dianjurkan oleh ajaran Islam ketika dan saat-saat anak baru dilahirkan maka seterusnya pada masa anak kedua orang tua dapat menciptakan jiwa keagamaan pada anak tersebut adalah:

1) Pada masa usia dibawah 4 tahun anak dikenalkan dengan perilaku-perilaku keagamaan, misalnya membaca basmallah pada setiap memulai pekerjaan, hamdalah setiap selesai melakukan pekerjaan, mengucapkan lafaz-lafaz lain yang sesuai dengan situasi dan kondisi, misalnya salam ketika akan keluar rumah dan akan masuk rumah dan ucapan-ucapan lain yang penting.

2) Pada usia lebih kurang 4-10 tahun, dibiasakan. Yaitu apa-apa yang telah dikenalkan pada masa diatas, anak diusahakan terus menerus melakukan perilaku keagamaan yang dilakukan terutama dalam kehidupan sehari-hari.

3) Pada masa usia lebih kurang 10-16 tahun, anak diajak memahami ajaran-ajaran Islam. Misalnya, bagaimana cara melakukan shalat yang sebenarnya.

4) Pada masa usia 16-21 tahun dan seterusnya, masa menganalisa, apa, mengapa, dan bagaimana ajaran Islam itu dilakukan, misalnya apa itu shalat, mengapa harus shalat, bagaimana shalat yang sebenarnya.

Dari uraian diatas dapat di tarik kesimpulan bahwasanya Penanaman jiwa keberagamaan pada anak dapat dilakukan dengan melalui langkah-langkah tersebut diatas .

Kegiatan pendidikan pada anak dalam keluarga memiliki tujuan tertentu yang ingin diwujudkan. Menurut Tafsir, (2012: 163) “Tujuan pendidikan anak dalam keluarga adalah agar 
anak itu menjadi anak yang shaleh". Indikasinya tercermin dalam perilaku sehari-hari dengan memperkokoh keimananya, rajin melakukan ibadah, baik ibadah magdhah maupun ibadah sosial, berbakti kepada kedua orang tua (birr al-walidain), berbuat baik kepada orang lain, memiliki kecenderungan untuk melakukan perbuatan baik kepada orang lain, memiliki kecenderungan untuk perbuatan kebajikan, selalu berusaha melakukan kegiatan-kegiatan yang bermanfaat baik bagi dirinya sendiri maupun orang lain, senantiasa menjauhi kemaksiatan, dan melakukan tindakantindakan positif lainnya.

Untuk mewujudkan anak yang shaleh itu banyak hambatan dan rintangan yang dihadapi orang tua. Anak sendiri secara otomatis dihadapkan kepada berbagai pengaruh negatif dari dalam maupun dari luar rumah. Pengaruh dari dalam rumah kebanyakan melalui media televisi pada acara tertentu yang tidak mendidik, sedangkan pengaruh negtif dari luar rumah terutama berupa arus budaya global yang menembus seluruh pelosok bumi ini. Modernisasi sendiri menyajikan realitas ganda, disatu sisi telah membantu kemudahan pemenuhan kebutuhan hidup anak melalui berbagai hasil sains dan teknologi yang sangat canggih. Akan tetapi disisi lain membahayakan perilaku anak itu sendiri yang semakin jauh dari tatanan ajaran-ajaran Islam.

Dalam kondisi seperti ini mendidik agama pada anak mengalami kesulitan tertentu. Kesulitan-kesulitan itu harus diatasi dengan berbagai cara. Salah satu caranya adalah melalui managemen pendidikan agama yang dikhususkan pada anak dalam keluarga. Anak perlu diarahkan agar dapat menemukan jalan yang benar, perlu diberikan contoh agar dapat meniru perbuatanperbuatan yang baik dan bermanfaat, perlu dibentuk kepribadiannya melalui pembudayaan agar memiliki kebiasaan-kebiasaan yang baik dalam mengarungi kehidupan di masyarakat, dan perlu diberikan informasi berbagai macam pengetahuan agar wawasannya semakin meluas.

Adapun dari segi jenis materi pendidikan agama Islam yang perlu disampaikan kepada anak dalam keluarga, Luqman Al-Hakim menerapkan urutan: keimanan (ketauhidan) berupa larangan menyekutukan Allah (QS. Luqman (31): 13) shalat, amar ma'ruf nahi munkar dan bersabar (QS.Luqman (31): 17) serta ahlak berupa larangan memalingkan muka karena sombong dan berjalan dimuka bumi dengan angkuh (QS.Luqman (31): 18). (Qomar, 2013: 6).

Inti dari materi pendidikan agama yang paling pokok dan seharusnya disajikan kepada anak dalam keluarga muslim adalah akidah, ibadah, dan akhlak. Materi akidah untuk membangun fondasi keimanan yang murni (tauhid) pada anak sehingga mereka mampu menghadapi guncangan keyakinan dari agama atau aliran lain apa pun coraknya. Materi ibadah untuk membangun kebiasaan dan kesadaran melakukan ibadah kepada Allah sebagai tindak lanjut dari keimananya itu, sedangkan materi akhlak untuk menghiasi dan menyempurnakan baik keimanan maupun ibadahnya kepada Allah SWT. Tiga materi pokok ini sering disebut dengan iman, Islam, dan ihsan. 
Apabila ketiga materi tersebut tertanam dengan kokoh pada diri anak dalam keluarga, maka mampu mewujudkan kepribadian Muslim yang utama. Ketika semua anggota keluarga Muslim memiliki dan mengamalkan ketiganya secara optimal, maka rumah tangganya menjadi rumah tangga yang disebut Nabi sebagai baitiy jannatiy (rumahku adalah surgaku). Inilah rahasia manajemen pendidikan agama yang dipraktikkan Luqman kepada anaknya yang dijadikan model oleh Al-Qur'an. (Saefullah, 2012:76)

Dari uraian di atas dapat ditarik kesimpulan bahwasanya pendidikan pada anak dalam keluarga memiliki tujuan tertentu yang hendak diwujudkan, tidak lain dan tidak bukan yaitu agar seorang anak menjadi anak yang shaleh, tentunya semua itu hanya dapat terwujud jika orang tua selaku pendidik dalam keluarga mampu memberikan pendidikan dan bimbingan yang sesuai dengan ajaran Agama, serta atas dasar keteladanan dari kedua orang tuanya. Karena memang seorang anak memiliki kecenderungan untuk mencontoh (imitasi).

Dengan mendasarkan pada substansi manajemen pendidikan agama pada anak dalam keluarga muslim yang dipraktikkan dan di dokumentasikan dalam Al-Qur'an surah Luqman, selanjutnya dari segi materi, managemen pendidikan Agama pada anak dalam keluarga Muslim dapat ditempuh dengan upaya-upaya sebagai berikut:

1) Mengembangkan dan menyempurnakan keimanan yang telah dibawa sejak lahir.

2) Menjauhkan diri dari syirik teologis maupun syirik sosial.

3) Melatih kebiasaan beribadah mahdhah dan senantiasa berusaha meningkatkanya.

4) Melatih kebiasaan beribadah sosial dan berusaha meningkatkanya.

5) Melatih kebiasan membaca Al-Qur'an, mempelajari dan mengamalkan isinya.

6) Menanamkan ahlak yang terpuji, baik dalam pemikiran, ucapan maupun perbuatan.

7) Menanamkan sikap berbakti kepada kedua orang tua.

8) Menanamkan sikap rendah hati pada orang lain terutama kepada orang yang lebih tua.

9) Menanamkan sikap tegas terhadap kebenaran.

10) Menanamkan sikap santun dalam bertutur kata.

Upaya-upaya tersebut sekaligus merupakan penyampaian materi pendidikan agama yang bisa diserap anak pada keluarga Muslim dalam rangka mewujudkan anak shaleh yang kokoh keimananya, tekun ibadahnya, anggun ahlaknya, dan peka kepeduliaan sosialnya. Kemudian dari segi mekanisme me-manage pendidikan Agama pada anak dalam keluarga muslim, orang tua seharusnya melakukan serangkaian tindakan sebagai berikut:

1) Senantiasa berusaha menjadi teladan dalam semua aspek kehidupan sehari-hari baik perbuatan, tingkah laku, perkataan, dan lain-lain yang dapat dijadikan percontohan yang bisa ditiru anak. 
2) Menerapkan kedisiplinan, konsistensi dan konsekuensi dalam melakukan perbuatan khususnya menyangkut ibadah.

3) Membentuk suasana rumah tangga yang dihiasi nilai-nilai Islam dalam berbagai segi perkataan, sikap, perbuatan, kebersihan, dan penjagaan lingkungan.

4) Membudayakan menerapkan akhlak yang terpuji (akhlak mahmudah) dalam semua hubungan baik hubungan dengan Allah, Rasul, Orang tua, saudara, kerabat, sahabat maupun masyarakat.

5) Membentuk keluarga sakinah mawaddah wa rahmah (keluarga damai penuh kasih sayang dan rahmat) yang diterapkan dalam kehidupan sehari-hari sehingga terasa damai, sejahtera dan menyejukkan hati.

6) Memberikan contoh kebiasaan shalat berjamaah khususnya shalat berjama'ah dimasjid.

7) Memberikan contoh kebiasaan mendengarkan pengajian baik melalui televisi, radio, tape recorder, pengajian rutin maupun pengajian umum.

8) Memberikan contoh kebiasaan berlangganan majalah-majalah yang menonjolkan kehidupan Islami.

9) Memberikan contoh kebiasaan memburu/ mencari ilmu pengetahuan agama Islam.

10) Mengondisikan kesibukan melalui pelibatan dalam berbagai kegiatan baik kegiatan keilmuan, kegiatan peribadahan maupun kegiatan sosial. (Qomar, 2013: 8).

Dari beberapa uraian diatas dapat di tarik kesimpulan, bahwasanya dari tindakan-tindakan yang dilakukan orang tua tersebut, dapat memberikan keteladanan bagi seorang anak, dan dari tindakan-tindakan itu diharapkan seorang anak dapat meniru kebiasaan baik yang dicontohkan oleh kedua orang tuanya serta dapat menerapkannya dalam kehidupan sehari-hari.

Kemudian orang tua juga berperan melakukan tindakan preventif terhadap anak, agar anak tidak tersesat dalam kehidupannya. Diantara beberapa cara yang bisa dilakukan yaitu: memisahkan pergaulan dari anak-anak nakal, mewaspadai adanya kemungkinan membuka situs-situs porno di internet ataupun handphone, membatasi waktu bermain game, dll.

\section{MANAJEMEN PENDIDIKAN AGAMA PADA REMAJA}

Sebenarnya masa remaja adalah masa peralihan, yang ditempuh oleh seseorang dari kanakkanak menuju dewasa. Atau dapat dikatakan bahwa masa remaja adalah perpanjangan masa kanakkanak sebelum mencapai usia dewasa. Anak-anak jelas kedudukannya. Yaitu yang belum dapat hidup sendiri, belum matang dari segala segi, tubuh masih kecil. Organ-organ belum dapat menjalankan fungsinya secara sempurna. Hidupnya masih bergantung pada orang dewasa, dan belum dapat diberi tanggung jawab atas segala hal. 
Kaum remaja memiliki persepsi khusus terhadap pengalaman ajaran-ajaran agama yang menjadi problem tersendiri ini dampak pada sikap dan perilaku dalam merespon ajaran agama. Intinya gejala remaja pada krisis akhlak, dalam bukunya dimensi manajemen pendidikan Islam oleh Qomar, (2013: 20-22) disebutkan bahwa faktor munculnya krisis akhlak deisebabkan banyak faktor salah satunya adalah faktor krisis akhlak terjadi karena longgarnya pegangan atau ajaran agama, kurangnya pembinaan moral oleh orang tua sekolah dan masyarakat, karena derasnya arus budaya, karan belum ada kemauan yang bersungguh-sungguh dari pemerintah. (Abdurrohman, 2005: 36-64)

Masa dewasa juga jelas. Pertumbuhan jasmani telah sempurna, kecerdasan dan emosi telah cukup berkembang. Akan tetapi, lain halnya dengan masa remaja. Jika dilihat tubuhnya, dia telah seperti orang dewasa, jasmaninya telah jelas berbentuk laki-laki atau wanita. Organ-organnya telah dapat pula menjalankan fungsinya. Dalam hidupnya mereka ingin berdiri sendiri, tidak bergantung lagi kepada orang tua atau orang dewasa lainnya, akan tetapi mereka belum mampu bertanggung jawab dalam soal ekonomi dan sosial.

Oleh karena itu pendidikan agama memiliki peran yang penting untuk mengawali atau membimbing anak remaja agar tidak mudah mengikuti arus globalisasi budaya. Ada langkahlangkah yang perlu ditempuh dalam mengelola pendidikan agama pada remaja di dalam keluarga seharusnya dikelola dengan baik. Dibawah ini adalah langkah-langkah pendidikan agam pada remaja. antara lain ialah:

1. Mengantisipasi penyimpangan-penyimpangan remaja

2. Mengarahkan perubahan perilaku yang menyimpang, menjauhkan larangan-larangan Allah dan menjalankan printah Allah

3. Memperdalam pemahaman keislamannya

4. Memberikan wawasan keislaman tentang pencipta alam semesta

5. Memberikan wawasan keislaman tentang pencipta alam semesta

6. Meneladani sholat dalam sehari-hari

7. Menanamkan sikap sopan santun kepada orang tua, guru, sahabat, tetangga, maupun masyarakat secara umum

8. Mengaji Al Quran

9. Berbanyak berzikir kepada Allah

10. Memberikan pergaulan dalam model wawasan keislaman

11. Memberikan wawasan tentang cara menghadapi masa depan secara islami.

12. Secara spiritual, orang tua hendak berdoa dan sholat hajat untuk memohon kepada Allah agar anaknya diberi petunjuk oleh Allah. 
Dalam mendidik remaja alangkah baiknya pendidik meniru kaidah-kaidah pendidikan yang menjadi kebijakan Rasulullah SAW sebagaimana yang diidentifikasi oleh Hafidz Abdurrahman dalam bukunya Qomar, (2013: 25) Ialah sebagai berikut: 1) pembinaan mental, 2) aplikatif, 3) memberi tugas sesuai kemampuan, 4) menyeru sesuai dengan tingkah pemahaman, 5) memperhatikan perbedaan individu, 6) tidak memperbanyak nasehat, 7) memberi nasehat pada waktu yang tepat, 8) mendahulukan yang terpenting dari yang penting, 9) motivasi memperbanyak kebaikan, 10) melupakan kesalahan masa silam, 11) memberi penghargaan dan hukuman, 12) hukuman diberikan terhadap kesalahan yang disengaja, 13) tidak ada sanksi setelah taubat, 14) memaafkan kesalahan di diantara banyak kebaikan, 15), memilih tugas yang paling ringan, 16) menilai diri sendiri, 17) terus memberi, tidak tergesah-gesah memetik hasil.

a. Kriteria masa remaja

Adapun kriteria memahami masa remaja dalam pendidikan agama antara lain ialah:

1. Perkembangan Agama Pada Masa Remaja

Segala persoalan dan problema yang terjadi pada remaja-remaja itu, sebenarnya bersangkutpaut dan barkait-kait dengan usia yang mereka lalui, dan tidak dapat dilepaskan dari pengaruh lingkungan di mana mereka hidup. Dalam hal itu, suatu faktor penting yang memegang peranan yang menentukan dalam kehidupan remaja adalah agama. Tapi sayang sekali, dunia modern kurang menyadari betapa penting dan hebatnya pengaruh agama dalam kehidupan manusia, terutama pada orang-orang yang sedang mengalami kegoncangan jiwa, dimana umur remaja terkenal dengan umur goncang, karena pertumbuhan yang dilaluinya dari segala bidang dan segi kehidupan.

2. Masa Remaja Awal (13-16 tahun)

Pada masa ini terjadi perubahan jasmani yang cepat, sehingga memungkinkan terjadinya kegoncangan emosi, kecemasan, dan kekhawatiran. Bahkan, kepercayaan agama yang telah tumbuh pada umur sebelumnya, mungkin pula mengalami kegoncangan. Kepercayaan kepada tuhan kadang-kadang sangat kuat, akan tetapi kadang-kadang menjadi berkurang yang terlihat pada cara ibadanya yang kadang-kadang rajin dan kadang-kadang malas. penghayatan rohani cenderung skeptis sehingga muncul keengganan dan kemalasan untuk melakukan berbagai kegiatan ritual yang selama ini dilakukannya dengan penuh kepatuhan.

Kegoncangan dalam keagamaan ini mungkin muncul, karena disebabkan oleh faktor internal maupun eksternal. Faktor internal berkaitan dengan matangnya organ seks, yang mendorong remaja untuk memenuhi kebutuhan tersebut, namun di sisi lain ia tahu bahwa perbuatannya itu dilarang oleh agama. Kondisi ini menimbulkan konflik pada diri remaja. Faktor internal lainnya adalah bersifat psikologis, yaitu sikap independen, keinginan untuk bebas, tidak mau terikat oleh normanorma keluarga (orangtua). Apabila orangtua atau guru-guru kurang memahami dan mendekatinya 
secara baik, bahkan dengan sikap keras, maka sikap itu akan muncul dalam bentuk tingkah laku negatif, seperti membandel, oposisi, menentang atau menyendiri, dan acuh tak acuh.

3. Masa Remaja Akhir (17-21 tahun)

Masa remaja terakhir dapat dikatakan bahwa anak pada waktu itu dari segi jasmani dan kecerdasan telah mendekati kesempurnaan. Yang berarti bahwa tubuh dengan seluruh anggotanya telah dapat berfungsi dengan baik, kecerdasan telah dianggap selesai pertumbuhannya, tinggal pengembangan dan penggunaannya saja yang perlu diperhatikan.

Akibat pertumbuhan dan perkembangan jasmani, serta kecerdasan yang telah mendekati sempurna, atau dalam istilah agama mungkin dapat dikatakan telah mencapai tingkat balighberakal, maka remaja itu merasa bahwa dirinya telah dewasa dan dapat berpikir logis. Di samping itu pengetahuan remaja juga telah berkembang pula, berbagai ilmu pengetahuan yang diajarkan oleh bermacam-macam guru sesuai dengan bidang keahlian mereka masing-masing telah memenuhi otak remaja. Remaja saat itu sedang berusaha untuk mencapai peningkatan dan kesempurnaan pribadinya, maka mereka juga ingin mengembangkan agama, mengikuti perkembangan dan alur jiwanya ynag sedang bertumbuh pesat itu.

Kendatipun kecerdasan remaja telah sampai kepada menuntut agar ajaran agama yang dia terima itu masuk akal, dapat difahami dan dijelaskan secara ilmiah dan orisinil, namun perasaan masih memegang peranan penting dalam sikap dan tindak agama remaja.

Diantara sebab kegoncangan perasaan, yang sering terjadi pada masa remaja terakhir itu adalah pertentangan dan ketidakserasian yang terdapat dalam keluarga, sekolah dan masyarakat. Disamping itu, yang juga menggelisahkan remaja adalah tampaknya perbedaan antara nilai-nilai akhlak yang diajarkan oleh agama dengan kelakuan orang dalam masyarakat. Terutama yang sangat menggelisahkan remaja, apabila pertentangan itu terlihat pada orangtua, guru-gurunya di sekolah, pemimpin-pemimpin dan tokoh-tokoh agama. Banyak lagi faktor yang menggoncangkan jiwa remaja, seyogyanya guru agama dapat memahaminya, agar dapat menyelami jiwa remaja itu, lalu membawa mereka kepada ajaran agama, sehingga ajaran agama yang mereka dapat itu, betul-betul dapat meredakan kegoncangan jiwa meraka.

b. Ciri - ciri Kesadaran beragama Yang Menonjol Pada Masa Remaja

1. Pengalaman ketuhanannya semakin bersifat individual.

Remaja semakin mengenal dirinya. Ia menemukan dirinya bukan hanya sekedar badan jasmaniah, tetapi merupakan suatu kehidupan psikologis rohaniah berupa pribadi. Remaja bersifat kritis terhadap dirinya sendiri dan segala sesuatu yang menjadi milik pribadinya. Ia menemukan pribadinya terpisah dari pribadi-pribadi lain dan terpisah pula dari alam sekitarnya. 
Penemuan diri pribadinya sebagai sesuatu yang berdiri sendiri menimbulkan rasa kesepian dan rasa terpisah dari pribadi lainnya. Secara formal dapat menambah kedalaman alam perasaan, akan tetapi sekaligus menjadi bertambah labil. Keadaan labil yang menekan menyebabkan si remaja mencari ketentraman dan pegangan hidup. Penghayatan kesepian, perasaan tidak berdaya menjadikan si remaja berpaling kepada Tuhan sebagai satu-satunya pegangan hidup, pelindung dan penunjuk jalan dalam goncangan psikologis yang dialaminya.

2. Keimanannya semakin menuju realitas yang sebenarnya

Terarahnya perhatian ke dunia dalam menimbulkan kecendrungan yang besar untuk merenungkan, mengkritik, dan menilai diri sendiri. Intropeksi diri ini dapat menimbulkan kesibukan untuk bertanya-tanya pada orang lain tentang dirinya mengenai keimanan dan kehidupan agamanya.

Dengan berkembangnya kemampuan berpikir secara abstrak, si remaja mampu pula menerima dan memahami ajaran agama yang berhubungan dengan masalah ghaib, abstrak dan rohaniah, seperti kehidupan alam kubur, hari kebangkitan dan lain-lain. Penggambaran anthropormofik atau memanusiakan Tuhan dan sifat-sifatNya lambat laun diganti dengan pemikiran yang lebih sesuai dengan realitas.

3. Peribadatan mulai disertai penghayatan yang tulus

Agama adalah pengalaman dan penghayatan dunia dalam seseorang tentang ketuhanan disertai keimanan dan peribadatan. Pada masa remaja dimulai pembentukan dan perkembnagan suatu sistem moral pribadi sejalan dengan pertumbuhan pengalaman keagamaan yang individual. Melalui kesadaran beragama dan pengalaman keTuhanan akhirnya remaja akan menemukan Tuhannya yang berarti menemukan kepribadiannya. Ia pun akan menemukan prinsip dan norma pegangan hidup, hati nurani, serta makna dan tujuan hidupnya. Kesadaran beragamanya menjadi otonomi subjektif dan mandiri sehingga sikap dan tingkah lakunya merupakan pencerminan keadaan dunia dalamnya, penampilan keimanan dan kepribadian yang mantap.

\section{Sikap Remaja Dalam Beragama}

Percaya ikut-ikutan ini biasanya dihasilkan oleh pendidikan agama secara sederhana yang didapat dari keluarga dan lingkungannya. Namun demikian ini biasanya hanya terjadi pada masa remaja awal (usia 13-16 tahun).

Setelah itu biasanya berkembang kepada cara yang lebih kritis dan sadar sesuai dengan perkembangan psikisnya.

5. Percaya dengan kesadaran

Semangat keagamaan dimulai dengan melihat kembali tentang masalah-masalah keagamaan yang mereka miliki sejak kecil. Mereka ingin menjalankan agama sebagai suatu lapangan yang baru 
untuk membuktikan pribadinya, karena ia tidak mau lagi beragama secara ikut-ikutan saja. Biasanya semangat agama tersebut terjadi pada usia 17 tahun atau 18 tahun.

6. Dalam bentuk positif

Yaitu berusaha melihat agama dengan pandangan kritis, tidak mau lagi menerima hal-hal yang tidak masuk akal. Mereka ingin memurnikan dan membebaskan agama dari bid'ah dan khurafat, dari kekakuan dan kekolotan.

7. Dalam bentuk negatif

Semangat keagamaan ini akan menjadi bentuk kegiatan yang berbentuk khurafi, yaitu kecendrungan remaja untuk mengambil pengaruh dari luar ke dalam masalah-masalah keagamaan, seperti bid'ah, khurafat dan kepercayaan-kepercayaan lainnya.

8. Percaya, tetapi agak ragu-ragu

Keraguan kepercayaan remaja terhadap agamanya dapat dibagi menjadi dua:

a) Keraguan disebabkan kegoncangan jiwa dan terjadinya proses perubahan dalam pribadinya. Hal ini merupakan kewajaran

b) Keraguan disebabkan adanya kontradiksi atas kenyataan yang dilihatnya dengan apa yang diyakininya, atau dengan pengetahuan yang dimiliki.

9. Tidak percaya atau cenderung atheis

Perkembangan ke arah tidak percaya pada tuhan sebenarnya mempunyai akar atau sumber dari masa kecil. Apabila seorang anak merasa tertekan oleh kekuasaan atau kezaliman orangtua, maka ia telah memendam suatu tantangan terhadap kekuasaan orangtua, selanjutnya terhadap kekuasaan apapun, termasuk kekuasaan tuhan.

\section{MANAJEMEN PENDIDIKAN AGAMA ISLAM PADA ORANG TUA}

Orang tua memegang peranan yang penting dan berpengaruh atas pendidikan anaknya. Sejak seorang anak lahir, ibunyalah yang selalu ada disampingnya. Oleh karena itu ia meniru perangai ibunya, ibu merupakan orang yang pertama dikenal anak, yang mula-mula menjadi temannya. Apapun yang dilakukan ibu dapat dimanfaatkan sebagai sarana edukatif. Pengaruh ayah terhadap anaknya besar pula, dimata anaknya ia seorang yang tinggi dan terpadu diantara orang-orang yang dikenalnya, ayah merupakan penolong utama lebih-lebih sebagai tulang punggung penghidupan bagi keluarganya.

Hal ini menunjukkan ciri-ciri dari watak rasa tanggung jawab setiap orang tua atas penghidupan anak-anak mereka untuk masa kini dan masa mendatang. Karenanya tidaklah diragukan bahwa tanggung jawab pendidikan agama secara mendasar terpikul pada orang tua namun perlu diperhatikan juga pendidikan pada orang tua itu sendiri seperti apa. Karenanya 
anak terkadang cenderung terhadap kebiasaan orang tua maka dari itu perlu dilihat bagaimana keaktifan orang tua dalam mengatur pendidikan agama dalam kepribadianya.

Banyak ditemukan kasus-kasus dimasyarakat sekitar kita bahwa pendidikan agama Isla pada orang tua lebih rendah bila dibandingkan dengan pendidikan anak. Terkadang orang tua berusaha mendidik anak untuk pergi ke masjid atau musholah dalam bentuk mendidik anaknya namun tanpa disadari bahwa yang mengajak belum maksimal menjalankan aktifitas keagamaanya karena banyak alasan kesibukan mencari nafkah padahal perkembangan anak sangat cepat untuk menuju masa transisi atau bisa disebut masa remaja dari masa anak-anak sampai masa dewasa.

Ada juga kasus yang sering jumpai banyak orang tua yang mengaku beragama Islam dan dalam kartu tanda penduduk (KTP) terdapat agama Islam namun belum maksimal menjalankan ibadah atau puasa di bulan ramadhan. Mereka bisa disebutkan Islam abangan sebagaimana hasil penelitian Clifford Gertz di Mojokuto (sekarang diperkirakan Pare, Kediri) yang membagi Islam Jawa menjadi tiga kategori yaitu santri, abangan dan priyayi. Mereka ini tidak mau disebut bukan Islam, anehnya juga mereka tidak menjalankan syariat Islam. Qomar (2013: 40)

Perlu diperhatikan apabila pendidikan anak lebih maksimal dari pada pendidikan agama kepada orang tua maka sebaiknya anak mampu mengarahkan orang tua atau saling mengingatkan agar terjadi kekuatan nilai-nilai keislaman yang tinggi. Qomar (2013: 41), menuliskan ada beberapa pendekatan bagi anak untuk menyarankan orang tuanya. Perlu diperhatikan, antara lain:

1. Pendekatan persuasif.

Pendekatan ini dengan cara membujuk orang tua secara halus. Selain itu juga mampu menghindarkan sikap konfrontasi antara anak dengan orang tuanya, melestarikan interaksi dengan harmonis, menghindarkan ketersinggungan rasa kepada orang tuanya.

2. Pendekatan rasional

Pendekatan ini meyakinkan orang tua dalam menjalankan ajaran-ajaran Islam memalui argumentasi yang dapat diterima oleh akal sehat. Dalam pendekatan ini anak menjelaskan ajakan atau saran kepada orang tua secara rasional, mudah dinalar dan mudah diterima oleh akal pikiranya. Penerapan ini banyak manfaat seperti orang tua mampu meyakini kebenaran ajaran-ajaran Islam dalam Quran maupun hadits, membenarkan ajaran-ajaran Islam yang selama ini kurang diperhatikan dan kurang diperhatikan dalam kehidupan sehari-hari, membongkar mistis atau rahasia kebenaran ketentuan wahyu ( $\mathrm{Al}$ Quran dan hadits).

3. Pendekatan rasa.

Dalam konteks ini anak dalam mengajak dan menyarankan orang tua melalui sentuhansentuhan perasaan. Perasaan tersebut bisa berbentuk rasa bersalah karena selama ini belum menjalankan ibadah kepada Allah sebagaimana mestinya, rasa berdosa karena kurang bersyukur, 
rasa menyesal karena telah menyia-nyiakan usia dan sebagainya. Pendekatan ini juga memiliki manfaat antara lain: introspeksi diri, pengakuan bersalah secara tulus tanpa ada paksaan, kesadaran untuk kembali dijalan yang benar.

4. Pendekatan spiritual.

Pendekatan ini merupakan upaya-upaya untuk menyadarkan orang tua dalam menjalankan ajaran-ajaran Islam yang memusatkan konsentarsi bermunajat kepada Allah. Pendekatan ini ditempuh guna memperkokoh fungsi nomor tiga diatas. Namun sebaliknya pendekatan ini diimplementasikan paling awal, dan diimplementasikan terus sepanjang proses menyadarkan sehingga sekaligus menempati urutan terakhir. Jadi posisi pendekatan ini sebagai pembuka dan penutup proses menyadaran itu. Pendekatan ini menumbuhkan berbagai manfaat antara lain dapat menyadarkan diri kepada Allah sebagai pembuka kesadaran orang tua melalui hidayah, makin meningkatkan ketaqwaan kepada Allah, mampu menembus interaksi batiniah antara anak dan orang tua, dan merespon interaksi positif anak dengan orang tua.

Empat pendekatan inilah yang harus dilakukan oleh seseorang anak terhadap orang tua dalam lingkungan keluarga. Tentunya anak sangat merasa keberatan bahkan acuh dalam hal seperti ini. Mungkin karena memang karakter anak lebih cenderung meniru sikap maupun kebijakan terhadap orang tua. Namun jika dilakukan secara berlahan akan mampu menghasilkan perubahan yang sangat positif.

\section{KESIMPULAN}

Keluarga adalah tempat yang pertama dalam membentuk kepribadian manusia dan tempat dia memperoleh kasih sayang, menumbuhkan perasaan serta mengenal cita-cita. Anggota keluarga yang paling awal dan pertama berperan dalam pembentukan kepribadian anak tersebut adalah kedua orang tuanya. Orang tua (ayah dan ibu) memegang peran penting dan sangat berpengaruh terhadap pendidikan anak-anaknya, karena sejak lahir kedua orang tuanyalah yang berada disampingnya. Ibu adalah figur pertama yang dikenal dan ditiru perangainya oleh anak. Karena itu dalam ajaran Islam tanggung jawab mendidik anak sebenarnya sudah dimulai ketika seseorang memilih pasangan hidup (istri). Dan dikarenakan pendidikan dalam keluarga itu sangat penting, maka orang tua selaku pendidik bagi anak-anaknya seyogyanya mampu memberikan teladan yang baik untuk anakanaknya dan dapat memanagemen pola pendidikan yang akan diterapkan kepada anak-anaknya. Demi suatu keberhasilan dalam mendidik seorang anak, agar anak mampu mengarungi kehidupan nantinya. 
Manajemen pendidikan agama Islam pada anak merupakan awal langkah yang baik untuk menanamkan nilai-nilai keagamaan agar anak tumbuh dengan prinsip akhlak, aqidah, dan ibadah yang baik serta mendidik anak sejak dini akan menghasilkan output yang maksimal.

Manajemen pendidikan remaja perlu adanya pengawasan dari orang tua yang begitu serius dengan menanamkan kegiatan seperti karang taruna, majelis ta'lim, kegiatan aktif di masjid, atau nuansa-nuansa kegiatan keislaman terhadap anak remaja sebagai bentuk pembentukan karakter. Hal ini untuk menghidar perilaku yang negatif terhadap anak remaja. Manajemen pendidikan pada orang tua didasari dengan berbagai pendekatan. Hal ini dapat dilakukan untuk siapa saja seperti pendekatan rasional, persuasif, rasa, spiritual. Karena memang pendidikan agama pada orang tua memang perlu keseriusan. Berbeda dengan pendidikan agama Islam pada anak maupun remaja.

\section{SARAN}

Penulis tentunya menyadari jika tulisan diatas masih terdapat banyak kesalahan dan jauh dari kesempurnaan. Penulis menyarankan (berpendapat) beberapa hal terkait menejemen pendidikan agama dalam keluarga yaitu: tidak diragukan lagi bahwa peran keluarga berada pada posisi paling depan diantara pihak-pihak yang berpengaruh. Diatas pundak orang tualah terletak tanggung jawab pendidikan yang benar, meluruskan aqidah, menanamkan nilai-nilai moral dalam benak anak-anak.

\section{DAFTAR RUJUKAN}

Ahyadi, Abdul, Aziz. 1995. Psikologi Agama. Bandung: Sinar Baru Al Gesindo.

Alaludin. 2002. Psikologi Agama. Jakarta; Raja Grafindo Persada.

Anwar, dan Arsyad Ahmad. 2007. Pendidikan Anak Usia Dini. Bandung. Alfabeta.

Daradjat, Zakiah. 1996. Ilmu Jiwa Agama. Jakarta: Bulan Bintang.

Haidar, Putra, Baulay dan Nurgaya. 2012. Pendidikan Islam Dalam Mencerdaskan Bangsa. Jakarta: PT Rineka Cipta.

Hari Soetjiningsih, Christina, 2018. Psikologi Perkembangan, Perkembangan Anak. Depok: Prenada Group.

Jalaluddin. 2012. Psikologi Agam. Jakarta: PT Raja Grafindo Persada.

Latief, I. N. A., \& Hafni, N. D. 2017. Pola Pendidikan Keluarga dalam Membendung Gaya Hidup Hedonis di Lingkungan Perindustrian. Tadris: Jurnal Penelitian dan Pemikiran Pendidikan Islam, 9(1), 71-86.

Mutohar, Prim Masrokan. 2013. Strategi Peningkatan Mutu dan Saing Lembaga Pendidikan Islam. Jogjakarta: Ar Ruzz Media.

Nata, Abudin. 2014. Metodologi Studi Islam. Jakarta: PT. Raja Grafindo.

Qomar, Mujamil. 2015. Dimensi Managemen Pendidikan Islam, Jakarta: Erlangga

Qomar, Mujamil. 2007. Strategi Baru Pengelolaan Lembaga Pendidikan Islam. Jakarta: Erlangga. 
Raharjo. 2012. Pengantar Ilmu Jiwa Agama. Semarang. Pustaka Rizki Putra.

Wahab, Rahmalina. 2010. Psikologi Agama, Palembang:CV. Grafika Telindo.

Yusuf, Kadar. 2013. Tafsir Tarbawi, Jakarta: Bumi Aksara.

Yusuf, Syamsu.2011. Psikologi Perkembangan Anak dan Remaja. Bandung: Rosdakarya.

Zuhdiyah. 2012. Psikologi Agama, Yogyakarta: Pustaka Felicha 